OPEN ACCESS

International Journal of

Environmental Research and

Public Health

ISSN 1660-4601

www.mdpi.com/journal/ijerph

Article

\title{
Arsenic and Other Metals' Presence in Biomarkers of Cambodians in Arsenic Contaminated Areas
}

\section{Penradee Chanpiwat ${ }^{1,2}$, Seiichiro Himeno ${ }^{3}$ and Suthipong Sthiannopkao ${ }^{4, *}$}

1 Environmental Research Institute, Chulalongkorn University, Phayathai Road, Pathumwan, Bangkok 10330, Thailand; E-Mail: pchanpiwat@gmail.com

2 Center of Excellence on Hazardous Substance Management (HSM), Chulalongkorn University, Bangkok 10330, Thailand

3 Department of Molecular Nutrition and Toxicology, Faculty of Pharmaceutical Sciences, Tokushima Bunri University, Tokushima 770-8514, Japan; E-Mail: himenos@ph.bunri-u.ac.jp

4 Department of Environmental Engineering, College of Engineering, Dong-A University, 37 Nakdong-Daero 550 Beon-gil, Saha-gu, Busan 604-714, Korea

* Author to whom correspondence should be addressed; E-Mail: suthisuthi@gmail.com; Tel.: +82-512-001-018; Fax: +82-512-007-683.

Academic Editors: Ravi Naidu and Mohammad Mahmudur Rahman

Received: 30 September 2015 / Accepted: 4 November 2015 / Published: 10 November 2015

Abstract: Chemical analyses of metal (Cr, Mn, Fe, Co, Ni, Cu, Zn, As, Mo, Ba, and Pb) concentrations in hair, nails, and urine of Cambodians in arsenic-contaminated areas who consumed groundwater daily showed elevated levels in these biomarkers for most metals of toxicological interest. The levels of metals in biomarkers corresponded to their levels in groundwater, especially for As, whose concentrations exceeded the WHO guidelines for drinking water. About $75.6 \%$ of hair samples from the population in this study contained As levels higher than the normal level in unexposed individuals $\left(1 \mathrm{mg} \cdot \mathrm{kg}^{-1}\right)$. Most of the population $(83.3 \%)$ showed As urinary levels exceeding the normal $\left(<50 \mathrm{ng} \cdot \mathrm{mg}^{-1}\right)$. These results indicate the possibility of arsenicosis symptoms in residents of the areas studied. Among the three biomarkers tested, hair has shown to be a reliable indicator of metal exposures. The levels of As $\left(r^{2}=0.633\right), \mathrm{Ba}\left(r^{2}=0.646\right), \mathrm{Fe}\left(r^{2}=0.595\right)$, and $\mathrm{Mo}\left(r^{2}=0.555\right)$ in hair were strongly positively associated with the levels of those metals in groundwater. In addition, significant weak correlations $(p<0.01)$ were found between levels of exposure to As and As concentrations in both nails $\left(r^{2}=0.544\right)$ and urine $\left(r^{2}=0.243\right)$. 
Keywords: arsenic; hair; nails; urine; biomarker; chronic exposure

\section{Introduction}

In complex modern societies, humans can be exposed on a daily basis to a wide range of chemicals and pollutants. These come not only from environmental sources such as air, soil, water, and food, but also from a variety of lifestyle and occupational activities [1]. Exposure to environmental pollution can be considered a main source of adverse human health impacts, around the globe. These negative health impacts are generally higher in the developing countries, the poorer ones more so, as poverty's consequences tend to include lack of investment in adequate treatment technology and weak environmental law enforcement [1]. Exposure to toxic chemicals in groundwater, for example arsenic and fluoride in East and Southeast Asian countries, is a well-known manifestation of this situation [2].

Since 1999, numerous incidents have been reported of groundwater contamination in Cambodia by metals such as arsenic (As), manganese $(\mathrm{Mn})$, and barium $(\mathrm{Ba})$, occurring in provinces located along the Mekong delta floodplains [3-9]. As the groundwater constitutes a significant drinking water source for Cambodians in rural areas (some 53\%), approximately 100,000 are believed exposed daily to several toxic metals through the pathway of ingestion [8,9]. Consumption of contaminated food such as rice and fish also contributes to metal exposure via the ingestion pathway [1]. Chronic exposure to such metals, even at low levels, can lead to disabilities, diseases, or even death $[1,10,11]$.

One way to assess the extent of environmental exposure to chemicals, and to screen their potential impacts on humans, is by conducting human biomonitoring (HBM). HBM has been a tool of interest for quantifying human exposure, and body responses, to environmental pollutants from as far back as the 19th century [12-16]. Numerous studies have employed HBM to investigate As exposure through drinking water. These have reported significant relationships between levels of As exposure and levels of As determined in several biomarkers, including in blood, urine, skin-scales, hair, and nails [17-21]. Still, research on the agreement of As concentrations found among the different biomarkers and the inter-relationships between As and other elements within each biomarker is still very limited. The objectives of this study were therefore to (i) determine the levels and relationships of metals in the hair, nails, and urine of Cambodia residents consuming As enriched groundwater; (ii) study the inter-relationships between As and other elements in each type of biomarker; and (iii) to confirm the agreement of As environmental exposure levels and As concentrations in different biomarkers.

\section{Materials and Methods}

\subsection{Study Areas}

Four villages located in two provinces in the southern part of Cambodia were selected for this present study (Figure 1). Based on a preliminary survey of As concentrations in groundwater conducted by a local Non-Governmental Organization, the villages Sambour (PS) and Preak Chrov (PC) in Prey Veng Province, as well as Chang Kaoh (CK) in Kandal Province, where As concentrations exceeded the WHO drinking water quality guideline of $10 \mu \mathrm{g} \cdot \mathrm{L}^{-1}$, were selected as As 
contaminated areas. The village of Kampong Toul (KT) in Kandal Province was selected as a non-polluted (control) area.

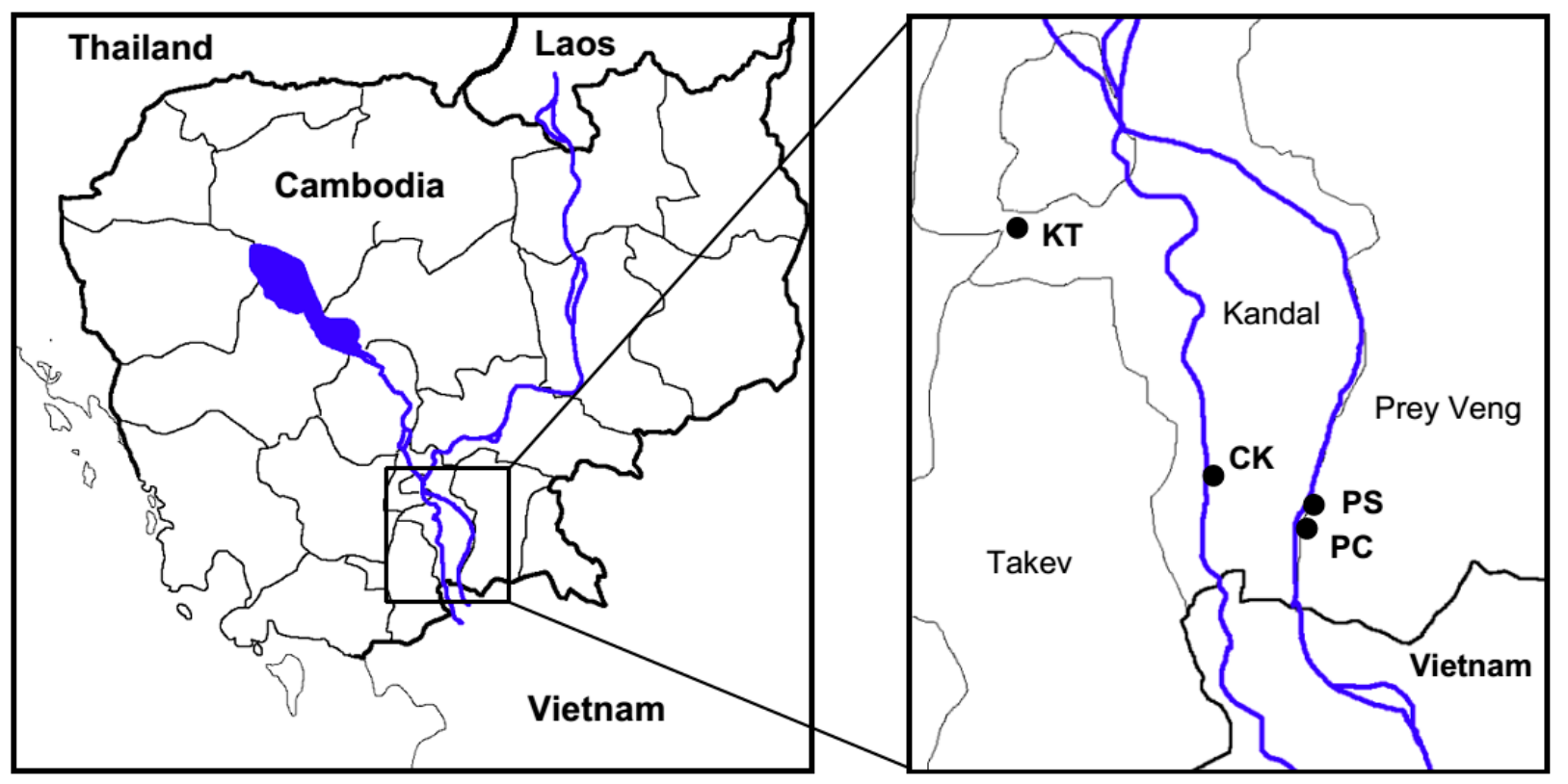

Figure 1. Locations of all areas studied along the Mekong River.

\subsection{Collection of Human Biomarkers}

The ethical approval for conducting health risk assessment using hair, nails, and urine of Cambodia residents in all areas studied was approved by the National Ethics Committee for Health Research (NECHR), Ministry of Health, Cambodia (Reference No. 180 NECHR).

A total of 180 individuals (50 from each contaminated area and 30 from the control area) were recruited as study subjects. The subject inclusion criteria used in this present study were a period of habitation in the study areas, as well as a period of continuous groundwater consumption, of at least one year. Prior to collection of biomarkers, each subject was informed by a local researcher about the purpose of this study with a document written in Khmer. In addition, the informed consent of each subject was obtained before the collection of hair, nails, and urine samples. Hair samples of about $1 \mathrm{~cm}$ were collected from the region of the head close to the scalp behind the ear. Nail samples were collected primarily from toenails. In very rare cases, (one case from $\mathrm{CK}$ and three cases from KT) samples of other nails supplemented these when the amount of toenail sample was not enough. For the urine samples, spot urine was collected from each subject and immediately kept on ice. After that, all urine samples were transferred to a liquid nitrogen tank and delivered to a laboratory.

\subsection{Collection of Groundwater}

At the same time, as the biomarker collection, 76 groundwater samples were collected from tube-wells used as a source of drinking water by subjects in the study. All groundwater samples were collected after 5 min of pumping. Once collected, each sample was filtered, acidified with nitric acid to a $\mathrm{pH}$ of less than 2 , then stored in an acid-washed tube until analysis. 


\subsection{Sample Pre-treatment}

In the laboratory, hair and nail samples were first cleaned according to the method described by Chen et al. (1999) [22]. In brief, hair and nail samples were immersed in 1\% Triton X-100, sonicated for $20 \mathrm{~min}$, washed 5 times with milli-Q water, and finally dried at $60{ }^{\circ} \mathrm{C}$ overnight in a drying oven. After that, all cleaned hair and nail samples were digested for total metal concentration with concentrated nitric acid (electrophoresis (EL) grade, an acid with very stringently limited concentrations of metallic impurities, purchased from Kanto Chemical Co, Inc., Tokyo, Japan) using a hot plate digestion method at $70{ }^{\circ} \mathrm{C}$ for $15 \mathrm{~min}$ and $115{ }^{\circ} \mathrm{C}$ for $15 \mathrm{~min}$ [23]. The final washing solution was collected to ensure that there were no particles or dust attached to cleansed hair. Concentrations of all metals of interest in the final washing solution were lower than the limit of detection for inductively coupled plasma mass spectrometry (ICP-MS; HP-7700x, Agilent Technologies, Kanagawa, Japan). For spot urine samples, all samples were digested in the same manner as the hair and nail sample digestion. After digestion, samples were diluted with $1.0 \%$ nitric acid and analyzed by ICP-MS.

In addition, a certified reference material (CRM) of cod fish tissue (National Metrology Institute of Japan (NMIJ) CRM 7402-a, No. 20) was also digested and analyzed by ICP-MS in the same manner as all biomarker samples to ensure the effectiveness of metal recovery by the digestion method. The percentage recoveries of all metals of interest were in the range of $83.6 \%$ to $86.9 \%$. Procedural blanks were also treated and analyzed in the same manner as all samples pre-treatment. The accuracy of instrument analysis was conducted by analyzing the standard reference material (SRM) of trace elements in water (SRM 1643e) purchased from National Institute of Standards and Technology (NIST), USA and analytical blanks after the analysis of every 20 samples. The percentage recoveries of instrumental analyses obtained were in the range of $85.7 \%$ to $105.1 \%$. Levels of all metals in procedural and analytical blanks were found to be lower than the limits of quantification as reported in Table 1 .

Table 1. Limits of quantification (LOQ) for metals in groundwater and biomarkers.

\begin{tabular}{|c|c|c|c|}
\hline \multirow{2}{*}{ Element } & \multicolumn{3}{|c|}{ Limit of Detection } \\
\hline & Groundwater $\left(\mu \mathrm{g} \cdot \mathrm{L}^{-1}\right)$ & Hair and Nails $\left(\mathrm{mg} \cdot \mathrm{kg}^{-1}\right)$ & Urine (ng $\cdot \mathrm{mg}^{-1}$ Creatinine) \\
\hline $\mathrm{Cr}$ & 0.38 & 0.10 & 0.10 \\
\hline $\mathrm{Mn}$ & 1.20 & 0.33 & 0.07 \\
\hline $\mathrm{Fe}$ & 2.78 & 2.93 & 0.09 \\
\hline Co & 0.32 & 0.01 & 0.04 \\
\hline $\mathrm{Ni}$ & 0.34 & 0.02 & 0.01 \\
\hline $\mathrm{Cu}$ & 0.29 & 0.12 & 0.04 \\
\hline $\mathrm{Zn}$ & 0.33 & 0.14 & 0.09 \\
\hline As & 0.55 & 0.03 & 0.02 \\
\hline Mo & 0.35 & 0.02 & 0.09 \\
\hline $\mathrm{Ba}$ & 1.36 & 0.79 & 0.02 \\
\hline $\mathrm{Pb}$ & 0.33 & 0.01 & 0.02 \\
\hline
\end{tabular}

\subsection{Sample Analyses}

Concentrations of metals contained in all water samples and in digested biomarker (hair, nail, and urine) samples were determined by ICP-MS with an online addition of germanium (1 ppm) as an 
internal standard. The ion signal for germanium at $\mathrm{m} / \mathrm{z} 72$ was found. The limits of quantification for metals in groundwater, hair, nail, and urine samples are summarized in Table 1. Duplications of all sample digestions and analyses were employed in this study.

Metal concentrations in urine were also determined by ICP-MS. Afterward their metabolized concentrations were adjusted with urinary creatinine and measured by a specific gravity method, to finally obtain the metal levels in urine in units of $\mathrm{ng} \cdot \mathrm{mg}^{-1}$ creatinine.

\subsection{Data Analyses}

All statistical analyses were performed using the Statistical Packages for Social Sciences (IBM SPSS) Software (version 15.0). Prior to statistical analysis, all data sets were tested for normality of distribution by the Komogorov-Smirnov test $(n>50)$. Since the distributions of the data sets were not normal, a nonparametric test, the Kruskal-Wallis $\mathrm{H}$, was applied to assess the regional differences in metal concentrations in groundwater, hair, nails, and urine. The correlation between each metal's concentration in groundwater and its corresponding concentration in a given biomarker, as well as the correlation of concentrations across biomarkers for a given metal, were analyzed by the Spearman's rho correlation statistic. The value of $p<0.01$ was used to judge the significance of differences and correlations for the parameters mentioned.

\section{Results and Discussion}

\subsection{Metals Concentrations in Groundwater}

Dissolved concentrations of metals in groundwater are summarized in Supplementary Materials (Tables S1-S4).

Overall, significant differences could not be found among concentrations of all metals except Fe, As, and Mo in groundwater collected from all areas studied. Compared to the control area (KT), significantly higher concentrations of $\mathrm{Fe}$, As, and Mo were found in samples collected from contaminated areas. This finding confirmed that the mobilization of As in study areas, floodplains along the Mekong River, was mainly caused by the desorption of As from As-bearing Fe oxides in sediments [8]. For this reason, high levels of Fe and As were determined in groundwater samples collected from all contaminated areas in the present study. Of the 76 collected groundwater samples, 84.2\% exceeded WHO (World Health Organization) drinking water guidelines for As concentrations, and $35.9 \%$ exceeded the guidelines for Ba. Since the WHO currently has regulations only for As $\left(10 \mu \mathrm{g} \cdot \mathrm{L}^{-1}\right)$ and $\mathrm{Ba}\left(700 \mu \mathrm{g} \cdot \mathrm{L}^{-1}\right)$ concentrations in groundwater [24], only percentages of groundwater samples containing As and Ba higher than the WHO guidelines were reported. All groundwater samples collected from PS, PC, and CK villages were found to be heavily contaminated by As. It was found that $100 \%$ of samples collected from CK, PC, and PS, the contaminated areas, contained As higher than the WHO guideline of $10 \mu \mathrm{g} \cdot \mathrm{L}^{-1}$. Ranges of concentrations of As in groundwater from the villages were 16.02-959 $\mu \mathrm{g} \cdot \mathrm{L}^{-1}$ for PS, 57.9-997 $\mu \mathrm{g} \cdot \mathrm{L}^{-1}$ for PC, and 402-923 $\mu \mathrm{g} \cdot \mathrm{L}^{-1}$ for CK. (Tables S2-S4). For $\mathrm{Ba}$, the percentages of samples collected from $\mathrm{CK}$ and $\mathrm{PC}$ which were contaminated with concentrations higher than the WHO guideline were $37.5 \%$ and $63.6 \%$, respectively. All samples collected from the control area, KT, showed levels of As and Ba well below the WHO guidelines. 
Concentrations of As determined in groundwater collected from the contaminated villages (PS, PC, and CK) in this study were of the same magnitude as those found in previous research conducted in both Prey Veng and Kandal provinces. For Prey Veng Province, it should be noted that As concentrations found in this study were about 2.8 times higher than the most recently reported As concentrations contained in groundwater collected from that province's Svay Chrum village (in the Peam Chor district) [25]. In Kandal Province, well water samples in the Kien Svay district and in Koh Thom contained As in concentrations reaching up to $943 \mu \mathrm{g} \cdot \mathrm{L}^{-1}$ and $1,832 \mu \mathrm{g} \cdot \mathrm{L}^{-1}$, respectively [21,26]. Phan et al. (2013) [26] also reported high Ba concentrations $\left(872-2653 \mu \mathrm{g} \cdot \mathrm{L}^{-1}\right)$ in groundwater collected from As contaminated areas. The levels of $\mathrm{Ba}$ in groundwater found in the present study were similar to those reported earlier $\left(24.55-2631 \mu \mathrm{g} \cdot \mathrm{L}^{-1}\right)$.

\subsection{Metal Concentrations in Hair}

The median concentrations of metals in all collected hair samples were $0.29 \mathrm{mg} \cdot \mathrm{kg}^{-1}$ for Cr, $17.92 \mathrm{mg} \cdot \mathrm{kg}^{-1}$ for Mn, $79.98 \mathrm{mg} \cdot \mathrm{kg}^{-1}$ for $\mathrm{Fe}, 0.06 \mathrm{mg} \cdot \mathrm{kg}^{-1}$ for Co, $0.70 \mathrm{mg} \cdot \mathrm{kg}^{-1}$ for Ni, $12.52 \mathrm{mg} \cdot \mathrm{kg}^{-1}$ for $\mathrm{Cu}, 255.4 \mathrm{mg} \cdot \mathrm{kg}^{-1}$ for $\mathrm{Zn}, 4.18 \mathrm{mg} \cdot \mathrm{kg}^{-1}$ for As, $0.07 \mathrm{mg} \cdot \mathrm{kg}^{-1}$ for $\mathrm{Mo}, 10.39 \mathrm{mg} \cdot \mathrm{kg}^{-1}$ for Ba, and $2.64 \mathrm{mg} \cdot \mathrm{kg}^{-1}$ for $\mathrm{Pb}$. The orders of metal concentrations found in hair were $\mathrm{Co}<\mathrm{Mo}<\mathrm{Cr}<\mathrm{Ni}<$ $\mathrm{Pb}<\mathrm{As}<\mathrm{Ba}<\mathrm{Cu}<\mathrm{Mn}<\mathrm{Fe}<\mathrm{Zn}$. Statistical analyses revealed significant differences in concentrations of all metals in hair samples collected from the areas studied. Only two areas (CK and PC) were identified with metals concentrations in hair which were statistically higher than the other areas. Hair samples collected from PC were found with $\mathrm{Mn}, \mathrm{Fe}, \mathrm{Cu}, \mathrm{As}, \mathrm{Ba}$, and $\mathrm{Pb}$ higher than in the samples collected from the other three areas (KT, CK, and PS) (Tables S1-S4). The high levels of these metals in hair corresponded to the high levels of these same metals found in groundwater samples collected from the PC area. Groundwater As concentrations in the CK area were higher than those in PC. However, higher significant differences were not obtained $(p>0.01)$. Along with the hair samples from KT, the groundwater samples from KT also yielded the lowest levels of Fe, As, Mo, and $\mathrm{Ba}$ among the four areas. It has been observed that the level of metals in groundwater is not the only factor affecting the accumulation of metals in biomarkers; other important factors include age, gender, individual susceptibility, period of groundwater consumption and amount of daily groundwater consumption $[18,20]$.

Generally, As is the element whose concentration is most often observed in hair and other types of biomarkers. Because earlier studies did not include levels of metals other than As in hair, only the hair As concentrations in this study could be compared to previous researchers' findings.

The ATSDR (Agency for Toxic Substances and Disease Registry) recommends the normal level of As in hair of unexposed individuals should be less than $1 \mathrm{mg} \cdot \mathrm{kg}^{-1}$ [27]. This As level has accordingly been a convenient, continuously employable indication of the threshold level of arsenicosis symptoms. In the present study, $91.3 \%$ of all subjects living in the As contaminated areas had hair As higher than this threshold level. No one living in the non-contaminated (KT) area was found with a hair As concentration higher than $1 \mathrm{mg} \cdot \mathrm{kg}^{-1}$. The percentage of subjects in the non-control areas measuring As in hair higher than the $1 \mathrm{mg} \cdot \mathrm{kg}^{-1}$ level was $90 \%$ in $\mathrm{CK}, 94 \%$ in $\mathrm{PC}$, and $88 \%$ in PS. These figures indicate the possibility of As toxicity among residents of the areas who chronically consume groundwater. The range of As concentrations in hair in this study $\left(0.03\right.$ to $\left.56.75 \mathrm{mg} \cdot \mathrm{kg}^{-1}\right)$ was 
comparable to those reported for Cambodian subjects' hair in previous studies. For example, the range of As concentrations in hair collected from the residents of As contaminated areas had been previously measured at 0.01-57.21 $\mathrm{mg} \cdot \mathrm{kg}^{-1}$ [8], 0.10-7.95 $\mathrm{mg} \cdot \mathrm{kg}^{-1}$ [21], and $0.06-30 \mathrm{mg} \cdot \mathrm{kg}^{-1}$ [28]. Sampson et al. (2008) [29] found hair As concentrations in a Cambodian village where arsenicosis symptoms had been diagnosed to be about 2.1-13.94 $\mathrm{mg} \cdot \mathrm{kg}^{-1}$. The ranges of As in hair in CK, PC, and PS were respectively $0.65-56.75 \mathrm{mg} \cdot \mathrm{kg}^{-1}, 0.27-22.69 \mathrm{mg} \cdot \mathrm{kg}^{-1}$, and $0.23-12.94 \mathrm{mg} \cdot \mathrm{kg}^{-1}$, (Table 2). The three non-control village areas investigated in this present study therefore seem vulnerable to toxicity from chronic arsenic exposure.

Table 2. As concentrations in groundwater and biomarkers in four provinces of Cambodia.

\begin{tabular}{|c|c|c|c|c|c|}
\hline \multirow{2}{*}{ Statistics } & \multirow{2}{*}{ Population } & \multicolumn{4}{|c|}{ Study Area } \\
\hline & & KT & CK & PC & PS \\
\hline \multicolumn{6}{|c|}{ Groundwater $\left(\mu \mathrm{g} \cdot \mathrm{L}^{-1}\right)$} \\
\hline No. of samples & 76 & 12 & 24 & 22 & 18 \\
\hline Min & $<\mathrm{LOQ}$ & $<$ LOQ & 402 & 57.93 & 16.02 \\
\hline $\operatorname{Max}$ & 997 & 8.36 & 923 & 997 & 959 \\
\hline Mean & 512 & 2.56 & 686 & 587 & 567 \\
\hline Median & 591 & 1.24 & 700 & 650 & 616 \\
\hline SE & 22.13 & 0.44 & 19.23 & 32.68 & 32.04 \\
\hline \multicolumn{6}{|c|}{ Hair $\left(\mathrm{mg} \cdot \mathrm{kg}^{-1}\right)$} \\
\hline No. of samples & 180 & 30 & 50 & 50 & 50 \\
\hline Min & 0.03 & 0.03 & 0.65 & 0.27 & 0.23 \\
\hline Max & 56.75 & 0.41 & 56.75 & 22.69 & 12.94 \\
\hline Mean & 5.93 & 0.17 & 9.69 & 7.37 & 4.19 \\
\hline Median & 4.18 & 0.16 & 6.37 & 6.78 & 4.12 \\
\hline SE & 0.52 & 0.02 & 1.44 & 0.79 & 0.36 \\
\hline \multicolumn{6}{|c|}{ Nails $\left(\mathrm{mg} \cdot \mathrm{kg}^{-1}\right)$} \\
\hline No. of samples & 176 & 27 & 49 & 50 & 50 \\
\hline Min & 0.11 & 0.11 & 0.77 & 1.14 & 0.55 \\
\hline Max & 23.24 & 0.88 & 23.24 & 18.48 & 14.41 \\
\hline Mean & 4.14 & 0.37 & 5.47 & 4.72 & 4.29 \\
\hline Median & 3.04 & 0.31 & 3.84 & 3.40 & 3.61 \\
\hline SE & 0.30 & 0.04 & 0.72 & 0.49 & 0.45 \\
\hline \multicolumn{6}{|c|}{ Urine (ng $\cdot \mathrm{mg}^{-1}$ creatinine) } \\
\hline No. of samples & 180 & 30 & 50 & 50 & 5 \\
\hline Min & 22.26 & 30.22 & 22.26 & 52.51 & 46.76 \\
\hline Max & 995 & 995 & 448 & 689 & 407 \\
\hline Mean & 124 & 107 & 81.07 & 199 & 103 \\
\hline Median & 86.77 & 60.04 & 64.40 & 159 & 84.02 \\
\hline SE & 9.21 & 32.32 & 8.64 & 20.63 & 8.97 \\
\hline
\end{tabular}

In addition, Table 3 summarizes the significant correlations between levels of $\mathrm{As}, \mathrm{Ba}, \mathrm{Cr}, \mathrm{Mn}, \mathrm{Fe}$, $\mathrm{Ni}$, and Mo in groundwater and the levels of those same metals present in the hair samples of subjects who consumed groundwater on a daily basis. The levels of As $\left(r^{2}=0.633\right)$ (Figure 2a), Ba $\left(r^{2}=0.646\right)$ 
(Figure 3a), Fe $\left(r^{2}=0.595\right)$ (Figure 3b), and Mo $\left(r^{2}=0.555\right)$ (Figure 3c) in hair were moderately positively associated with the levels of these metals in the groundwater, which all residents in this study relied on as their sole source of drinking water. It is also worth noting that the highest Fe concentration $\left(134,700 \mathrm{mg} \cdot \mathrm{kg}^{-1}\right)$ in hair was in a male resident who had been exposed to the highest level of $\mathrm{Fe}$ in groundwater $\left(12,350 \mu \mathrm{g} \cdot \mathrm{L}^{-1}\right)$. The results clearly indicated that groundwater used as drinking water was the source of various metal exposures. Since the desorption of As from As-bearing $\mathrm{Fe}(-\mathrm{Mn})$ oxides in sediments was the key factor mobilizing As in groundwater, the higher exposure and accumulation in biomarkers was observed.
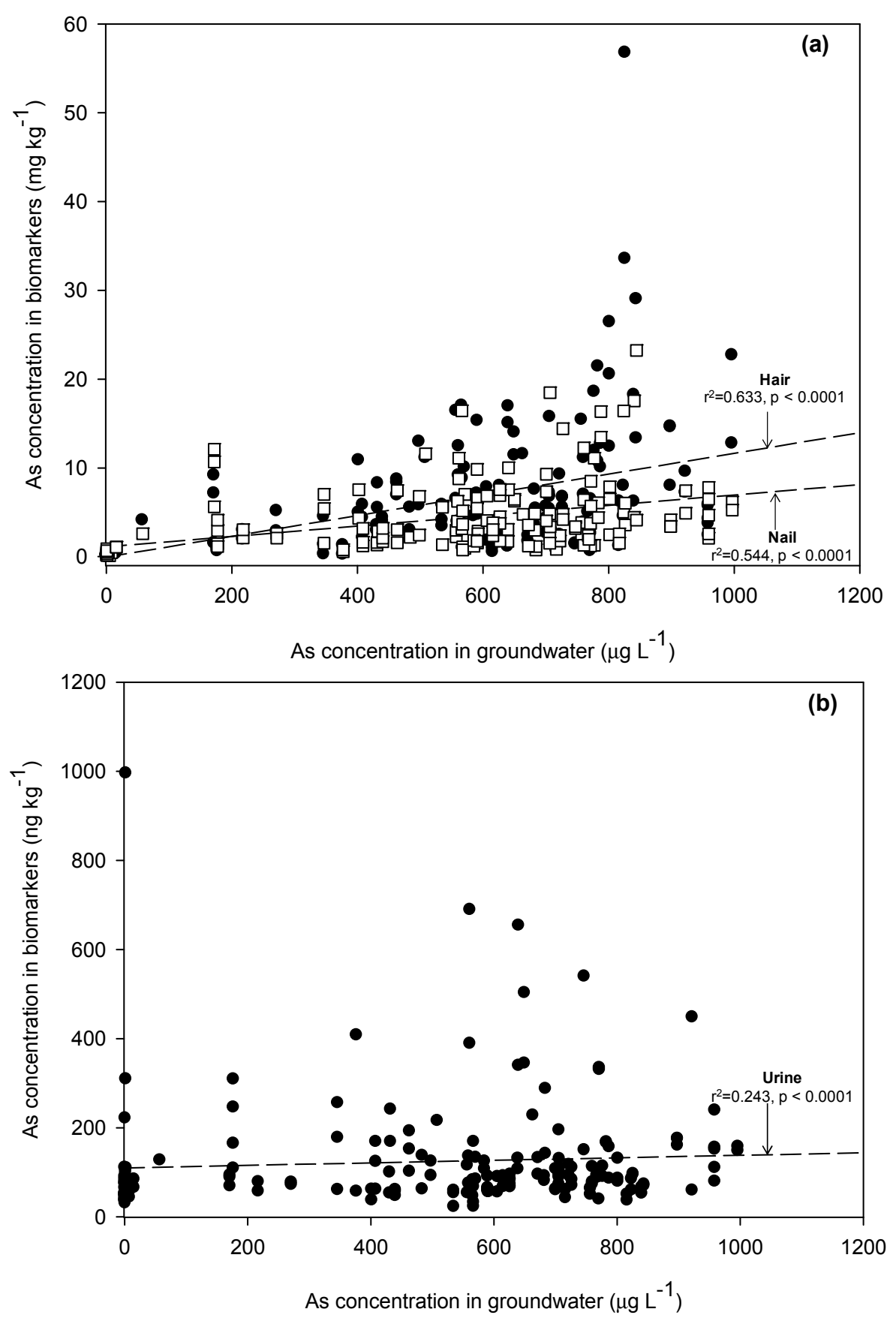

Figure 2. (a) Relationships of As in groundwater to biomarkers in hair and nails. (b) Relationships of As in groundwater to biomarkers in urine. 

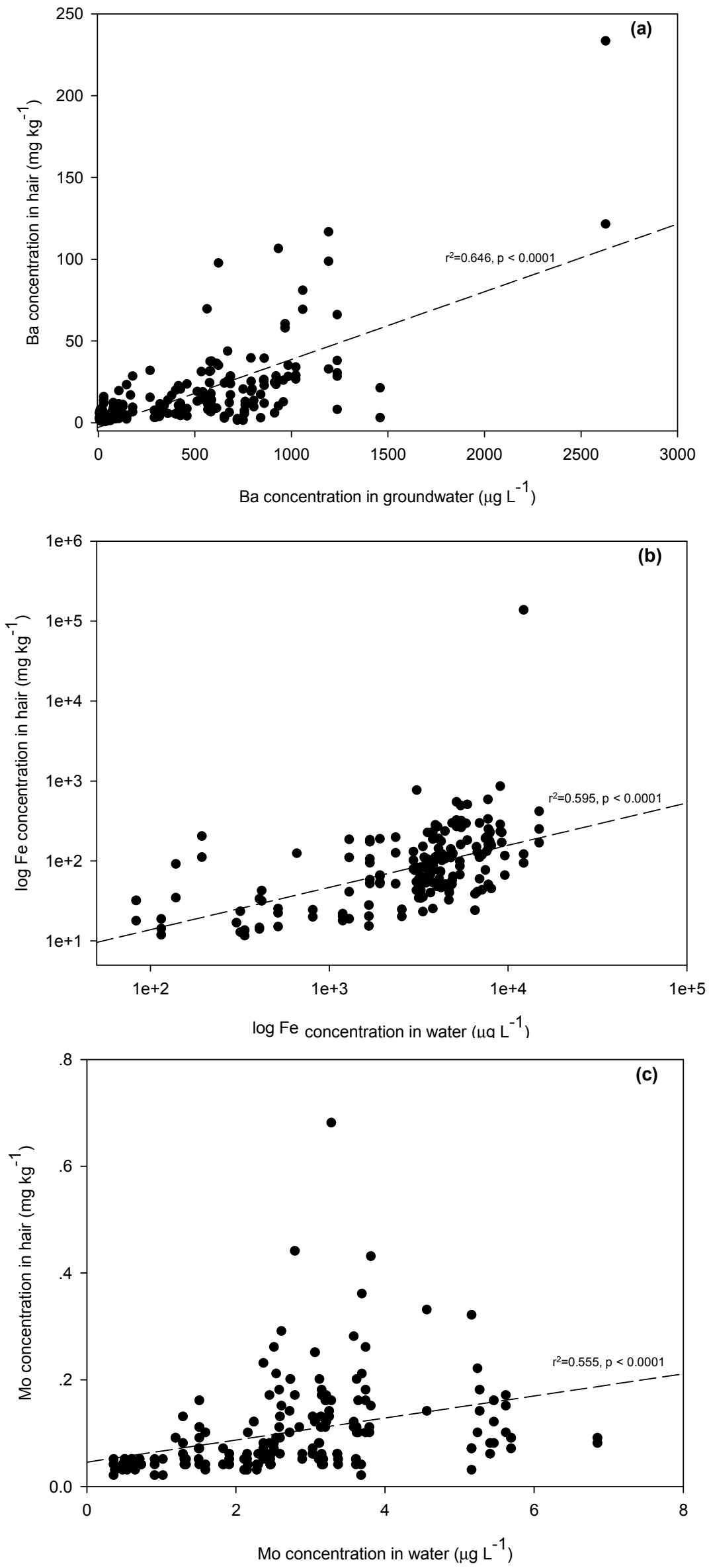

Figures 3. Relationships of (a) $\mathrm{Ba}$, (b) Fe, and (c) Mo in groundwater to hair samples. 


\subsection{Metal Concentrations in Nails}

The rank ordering of metal concentrations found in nails was somewhat similar to that for hair. The median levels of metals in nails, from lowest to highest concentrations, were $0.05 \mathrm{mg} \cdot \mathrm{kg}^{-1} \mathrm{Mo}$, $0.35 \mathrm{mg} \cdot \mathrm{kg}^{-1} \mathrm{Co}, 1.30 \mathrm{mg} \cdot \mathrm{kg}^{-1} \mathrm{~Pb}, 1.40 \mathrm{mg} \cdot \mathrm{kg}^{-1} \mathrm{Ni}, 1.64 \mathrm{mg} \cdot \mathrm{kg}^{-1} \mathrm{Cr}, 3.04 \mathrm{mg} \cdot \mathrm{kg}^{-1} \mathrm{As}, 4.95 \mathrm{mg} \cdot \mathrm{kg}^{-1}$ $\mathrm{Cu}, 10.07 \mathrm{mg} \cdot \mathrm{kg}^{-1} \mathrm{Ba}, 25.46 \mathrm{mg} \cdot \mathrm{kg}^{-1} \mathrm{Mn}, 113.0 \mathrm{mg} \cdot \mathrm{kg}^{-1} \mathrm{Zn}$, and $875.7 \mathrm{mg} \cdot \mathrm{kg}^{-1} \mathrm{Fe}$. Concentrations of $\mathrm{Cr}, \mathrm{Mn}, \mathrm{Fe}, \mathrm{Co}, \mathrm{Ni}, \mathrm{Cu}$, and $\mathrm{Ba}$ in nails collected from the $\mathrm{PC}$ area were significantly higher than in those from the other study areas. This is in agreement with the metal concentrations measured in groundwater samples, where the higher concentrations were usually detected in the PC area (Table 2, Table S3). Significantly lower $\mathrm{Cr}, \mathrm{Mn}, \mathrm{Fe}, \mathrm{Co}, \mathrm{Ni}, \mathrm{Cu}, \mathrm{Zn}, \mathrm{As}, \mathrm{Ba}$, and $\mathrm{Pb}$ concentrations were found in samples collected from the control area.

For As concentrations in nails, the ATSDR also recommends $1 \mathrm{mg} \cdot \mathrm{kg}^{-1}$ as the normal level for unexposed individuals [27]. In this study, only nail samples collected from the uncontaminated control area (KT) contained As levels lower than this normal level (Table 2). About $96.0 \%$ of the entire subject population living in the As contaminated areas had As levels in nails higher than the ASTDR recommended level. Overall, most concentrations of As in nails found in this present study did fall within the range of background As levels in nails $\left(<1.5\right.$ to $\left.7.7 \mathrm{mg} \cdot \mathrm{kg}^{-1}\right)$ as noted by Hughes (2006) [30]. However, $10.7 \%$ of the population in this study was found with As levels in nails higher than the background range, among which the upper end of As concentrations was about 3 times higher than this background level.

In addition, significant relationships between $\mathrm{As}, \mathrm{Ba}, \mathrm{Fe}$, and $\mathrm{Ni}$ concentrations in nail and groundwater samples were determined (Table 3). However, a strong positive correlation was found only for As $\left(r^{2}=0.544\right)$ (Figure 2a).

\subsection{Arsenic Concentrations in Urine}

ICP-MS analyses of metal concentrations in urine revealed different orderings compared to those of both hair and nail samples. The levels of metals found in urine, ranged from lowest to highest, were $0.36 \mathrm{ng} \cdot \mathrm{mg}^{-1} \mathrm{Co}, 1.23 \mathrm{ng} \cdot \mathrm{mg}^{-1} \mathrm{Mn}, 1.69 \mathrm{ng} \cdot \mathrm{mg}^{-1} \mathrm{Cr}, 2.38 \mathrm{ng} \cdot \mathrm{mg}^{-1} \mathrm{~Pb}, 8.85 \mathrm{ng} \cdot \mathrm{mg}^{-1} \mathrm{Ni}, 11.10$ $\mathrm{ng} \cdot \mathrm{mg}^{-1} \mathrm{Cu}, 12.33 \mathrm{ng} \cdot \mathrm{mg}^{-1} \mathrm{Ba}, 38.63 \mathrm{ng} \cdot \mathrm{mg}^{-1} \mathrm{Fe}, 65.87 \mathrm{ng} \cdot \mathrm{mg}^{-1} \mathrm{Mo}, 86.77 \mathrm{ng} \cdot \mathrm{mg}^{-1} \mathrm{As}$, and 388.7 $\mathrm{ng} \cdot \mathrm{mg}^{-1} \mathrm{Zn}$. However, $\mathrm{Mn}, \mathrm{Fe}, \mathrm{Ni}$, and As concentrations were found to be statistically different among the study areas (Tables S1-S4). No good agreement between metal concentrations in groundwater and in urine was found. However, lower metal concentrations in individuals' urine were reported in the urine samples collected from uncontaminated areas. Urine samples from PC village, which had the highest As groundwater concentration, were also highest in As (Table S3. It can be concluded that the higher the As exposure level, the higher the excretion of As from the human body, since As has no essential metabolic function. Though the background levels of urinary As can be found within the range of 5 to $50 \mathrm{ng} \cdot \mathrm{mg}^{-1}$, excessive exposure to As in groundwater could lead to urinary As levels exceeding $700 \mathrm{ng} \cdot \mathrm{mg}^{-1}$ [30]. In the control $\mathrm{KT}$ area, 57.1\% of urinary samples had As higher than the background level, as did $65.2 \%$ in CK, $100 \%$ in PC, and $100 \%$ in PS. Furthermore, about $1.2 \%$ of the whole population in this study was found with urinary As higher than $700 \mathrm{ng} \cdot \mathrm{mg}^{-1}$. An epidemiological study of environmental As exposure in Kandal Province has shown that the urinary 
As levels in both asymptomatic $\left(73.04 \pm 52.24 \mathrm{ng} \cdot \mathrm{mg}^{-1}\right)$ and arsenicosis patients $(78.74 \pm 69.84$ $\mathrm{ng} \cdot \mathrm{mg}^{-1}$ ) were not significantly different [18]. Noting that the levels of urinary As from subjects in KT village consuming As-free groundwater $\left(0.54-8.36 \mu \mathrm{g} \cdot \mathrm{L}^{-1}\right)$ were not statistically different from those of subjects consuming As-enriched groundwater, the results of urinary As obtained from this present study could not solely be used to indicate the level of As exposure or predict the development of individual As health impacts. Phan et al. (2014) [18] concluded that though villagers were not exposed to As contaminated groundwater, they could still be exposed to As, particularly through foodstuffs. Only one weakly positive correlation $\left(r^{2}=0.243\right)$, which was for As, was found between levels of metal exposure and concentrations of metal in urine (Table 3 and Figure $2 b$ ).

\subsection{Comparison of Metal Concentrations in Biomarkers and Agreement among Different Biomarkers}

Two other studies, by Samanta et al., 2004 [20] and Coelho et al., 2012 [31], have looked at concentrations of other metals in addition to As in biomarkers of individuals who were exposed environmentally and occupationally. Concentrations of most metals of interest in this study were even higher than in those researchers' populations (in India and Portugal). Groups of Indians had been exposed to $\mathrm{Mn}, \mathrm{Fe}$, and $\mathrm{Zn}$ through ingestion of groundwater [20]. Concentrations of these same metals in hair and in nail samples in the present study were respectively about 1.8 to 12.4 and 1.2 to 1.6 times higher than in the Indian residents. Taking another comparison, concentrations of $\mathrm{Cr}, \mathrm{Mn}$, and $\mathrm{Pb}$ contained in hair and nails of Cambodian subjects in this study were about 1.6 to 22.3 times higher than the concentrations of these metals in the same biomarkers in workers in the mining areas of Portugal [31]. These results strongly confirm the relatively high level of metals exposure experienced by our subject population. Individuals exposed to these metals will have accumulated some amounts of them in their tissues, in addition to their presence in biomarkers.

To compare the different levels of metals contained in different biomarkers within each individual studied, a Wilcoxon Signed-Rank Test was performed. A statistical analyses (by pairwise comparisons) revealed significant differences $(p<0.01)$ in the individual median concentrations of Fe, $\mathrm{Co}, \mathrm{Ni}, \mathrm{Zn}, \mathrm{As}$, and Mo in all three biomarkers. The negative Z-values shown in Table 4 tell that the statistics are based on negative ranks, meaning when there was an increase in a specific metal concentration in one biomarker, there was a significant decrease in the same metal concentration in the other biomarker. This finding fits with the notion of extensive biotransformation of ingested As by the human body. Specifically, because the body can excrete about $40 \%$ to $70 \%$ of the total ingested inorganic As within about $48 \mathrm{~h}$ [8], the higher the amount of As excreted the lower the amount of As accumulating in hair and nails. Table 4 also summarizes the varying rank orders of metal concentrations for each pair of biomarkers. Note that for different metals, different sequences of biomarkers would retain the highest to lowest concentrations. Table 5 displays correlations of concentrations of the same metal as found in two biomarkers, reflecting the relative propensity of each to retain the metal following exposure. 
Table 3. Correlations of metal concentrations in biomarkers to concentrations in groundwater.

\begin{tabular}{|c|c|c|c|c|c|c|c|c|c|c|c|}
\hline Biomarker & As & $\mathbf{B a}$ & $\mathrm{Cr}$ & Mn & $\mathrm{Fe}$ & Co & $\mathbf{N i}$ & $\mathbf{C u}$ & Zn & Mo & $\mathbf{P b}$ \\
\hline Hair & $0.633 * *$ & $0.646 * *$ & $-0.388 * *$ & $0.234 * *$ & $0.595 * *$ & 0.149 & $-0.287 * *$ & -0.017 & 0.132 & $0.555 * *$ & 0.027 \\
\hline Nail & $0.544 * *$ & $0.306 * *$ & -0.111 & -0.073 & $0.296 * *$ & $-0.176 * *$ & $-0.202 * *$ & -0.076 & 0.008 & 0.082 & -0.004 \\
\hline Urine & $0.243 * *$ & -0.104 & 0.018 & 0.008 & 0.033 & 0.112 & -0.014 & -0.103 & -0.014 & 0.122 & 0.031 \\
\hline
\end{tabular}

Table 4. Comparisons of metal concentrations in each biomarker for assessed subjects.

\begin{tabular}{|c|c|c|c|c|}
\hline \multirow{2}{*}{ Metal } & \multicolumn{3}{|c|}{$\begin{array}{c}\text { Statistical Analyses for Comparisons Of Metal Concentrations in } \\
\text { Each Pair of Biomarkers ( } \mathrm{Z}-\text { and } p \text {-Values) }\end{array}$} & \multirow{2}{*}{ Order of Biomarkers by Concentration of Each Metal } \\
\hline & Hair-Nail & Hair-Urine & Nail-Urine & \\
\hline $\mathrm{Cr}$ & $-10.459 ;<0.0001$ & $-10.596 ;<0.0001$ & $-2.215 ; 0.027$ & Hair $<$ Nail $<$ Urine \\
\hline $\mathrm{Mn}$ & $-1.970 ; 0.049$ & $-10.738 ;<0.0001$ & $-10.617 ;<0.0001$ & Urine $<$ Hair $<$ Nail \\
\hline $\mathrm{Fe}$ & $-11.096 ;<0.0001$ & $-4.868 ;<0.0001$ & $-11.237 ;<0.0001$ & Urine $<$ Hair $<$ Nail \\
\hline Co & $-10.992 ;<0.0001$ & $-11.557 ;<0.0001$ & $-1.337 ;<0.0001$ & Hair $<$ Nail $<$ Urine \\
\hline $\mathrm{Ni}$ & $-6.158 ;<0.0001$ & $-11.456 ;<0.0001$ & $-11.078 ;<0.0001$ & Hair $<$ Nail $<$ Urine \\
\hline $\mathrm{Cu}$ & $-10.565 ;<0.0001$ & $-2.247 ; 0.025$ & $-9.728 ;<0.0001$ & Urine $<$ Hair $<$ Nail \\
\hline $\mathrm{Zn}$ & $-10.954 ;<0.0001$ & $-3.560 ;<0.0001$ & $-11.272 ;<0.0001$ & Nail $<$ Hair $<$ Urine \\
\hline As & $-3.427 ;<0.0001$ & $-11.635 ;<0.0001$ & $-11.505 ;<0.0001$ & Nail $<$ Hair $<$ Urine \\
\hline Mo & $-7.434 ;<0.0001$ & $-11.635 ;<0.0001$ & $-11.505 ;<0.0001$ & Nail $<$ Hair $<$ Urine \\
\hline $\mathrm{Ba}$ & $-1.848 ; 0.065$ & $-0.895 ; 0.371$ & $-2.649 ; 0.008$ & Nail $<$ Hair $<$ Urine \\
\hline $\mathrm{Pb}$ & $-7.837 ;<0.0001$ & $-2.103 ; 0.035$ & $-6.093 ;<0.0001$ & Urine $<$ Hair $<$ Nail \\
\hline
\end{tabular}

Table 5. Correlations of metal concentrations among biomarkers.

\begin{tabular}{|c|c|c|c|c|c|c|c|c|c|c|c|}
\hline Biomarker & As & $\mathbf{B a}$ & $\mathrm{Cr}$ & Mn & $\mathbf{F e}$ & Co & $\mathrm{Ni}$ & $\mathbf{C u}$ & Zn & Mo & $\mathbf{P b}$ \\
\hline Hair-Nail & $0.721 * *$ & $0.341 * *$ & 0.067 & $0.315 * *$ & $0.358 * *$ & $0.203 * *$ & 0.079 & 0.102 & -0.019 & 0.079 & $0.276 * *$ \\
\hline Hair-Urine & $0.275 * *$ & -0.069 & 0.023 & 0.057 & 0.099 & 0.038 & -0.034 & -0.018 & -0.079 & 0.069 & -0.026 \\
\hline Nail-Urine & $0.297 * *$ & -0.112 & -0.077 & -0.096 & -0.030 & -0.084 & 0.033 & -0.082 & 0.078 & 0.006 & -0.134 \\
\hline
\end{tabular}

$* *$ Correlation is significant at the 0.01 level (2-tailed). 
As shown in Table 5, significant $(p<0.01)$, though weak, correlations between concentrations found in hair and nails occurred for $\mathrm{Ba}\left(r^{2}=0.341\right), \mathrm{Mn}\left(r^{2}=0.315\right), \mathrm{Fe}\left(r^{2}=0.358\right)$, Co $\left(r^{2}=0.203\right)$, and $\mathrm{Pb}\left(r^{2}=0.276\right)$. Since hair and nails are rich in keratin, which has a high affinity for As, elevated concentrations of As were, as expected, found. Thus, keratin containing cysteine residue with sulfhydryl groups can result in As and sulfur complexation in both hair and nails [20]. Hair and nails in a similar manner incorporate other elements such as $\mathrm{Fe}, \mathrm{Mn}, \mathrm{Ni}$, and $\mathrm{Pb}$. The results of this study agree well with those of Samanta et al. (2004) [20], who found that $\mathrm{Zn}, \mathrm{Cu}, \mathrm{Fe}$, and $\mathrm{Mn}$, which are associated with enzymes, generally show higher ranges of concentrations in hair, nails, and skin-scale than the other elements do. In addition, there were significant positive correlations between amounts of As in all the different biomarker pairs (Hair-Nail: $r^{2}=0.721$ (Figure 4), Hair-Urine: $r^{2}=0.275$, Nail-Urine: $r^{2}=0.297$ ). For $\mathrm{Cr}, \mathrm{Ni}, \mathrm{Cu}, \mathrm{Zn}$, and $\mathrm{Mo}$, such strong relationships between amounts in hair, nails, and urine pairs could not be observed. It can be concluded from the results of such correlation analyses that hair can be considered a good biomarker for degree of environmental exposure to a variety of metals. In particular, As levels in hair and in nails can be used to indicate chronic exposure arsenic [32]. Levels of metals in urine, especially As, can be considered to indicate only recent exposure; urinary As is usually eliminated within 3-4 days [33]. The sample collection, treatment, and analysis of hair are moreover easy, practical, ethically innocuous, cost-efficient, and of high toxicological relevance compared, on these attributes, to sampling nails and urine. $[15,16]$.

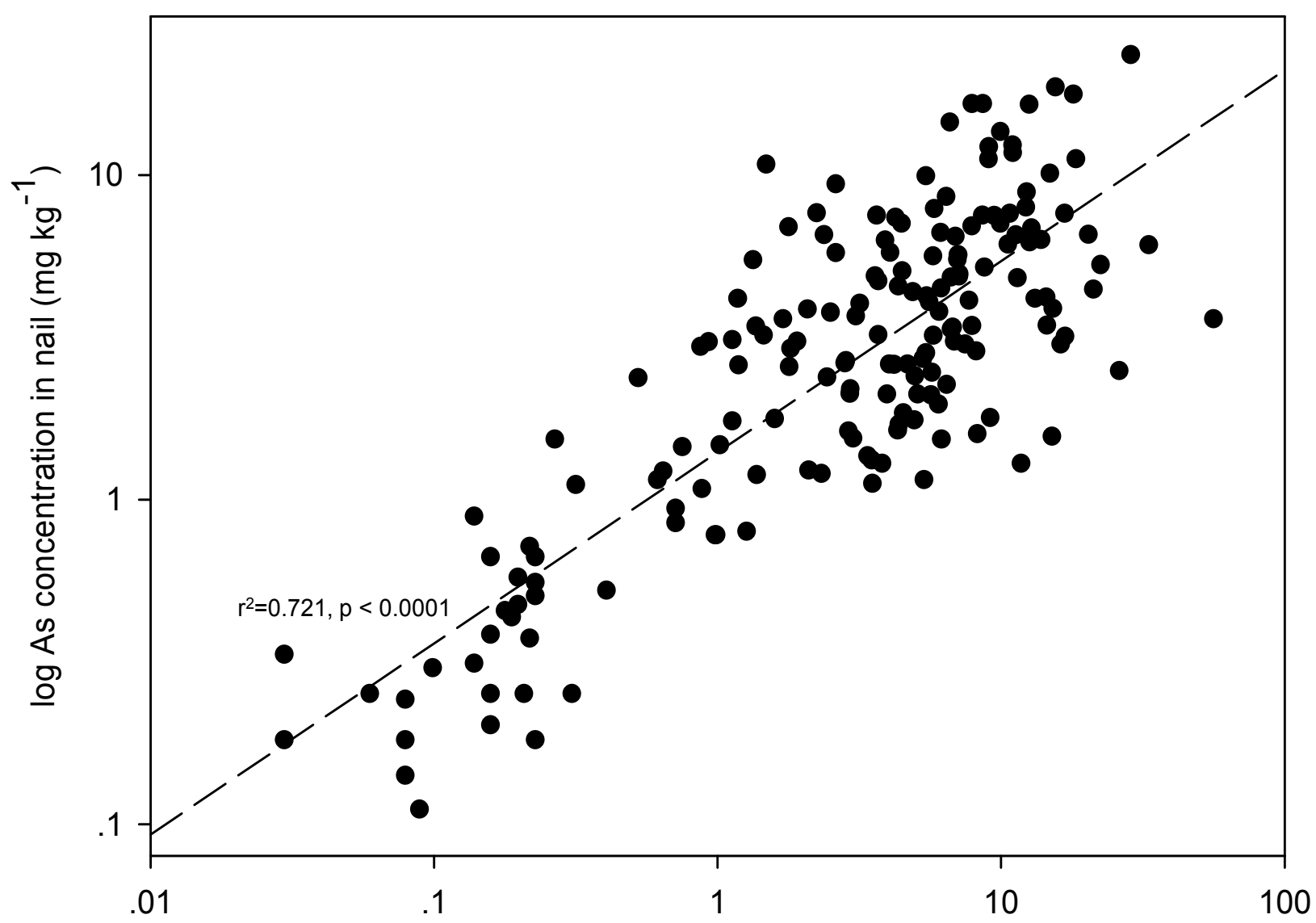

$\log$ As concentration in hair $\left(\mathrm{mg} \mathrm{kg}^{-1}\right)$

Figure 4. The relationship of As levels in hair and nails. 
The As concentrations in urine collected from subjects in the non-contaminated area (KT) and those collected in the contaminated areas (CK, PC, and PS) were not statistically different can be explained by the consumption in KT of contaminated food, especially fish and rice cultivated in Kandal, the province where KT village is located. It was reported by Wang et al. [34] that the daily intake of arsenic via food consumption in Kandal would contribute approximately $604 \mu \mathrm{g} \cdot \mathrm{day}^{-1}$ of As exposure. Interestingly, fish consumption was found to account for the greatest proportion of total As daily intake in Kandal. Data on individual residents' fish consumption in the KT area supported this hypothesis well, with subjects in this study ordinarily consuming fish three to seven times weekly.

\section{Conclusions}

This study was conducted in As-contaminated areas of Cambodia, where most groundwater drinking water sources contain As concentrations higher than $10 \mu \mathrm{g} \cdot \mathrm{L}^{-1}$. Elevated levels of As in biomarkers among the local population were therefore expected. Measured concentrations of As in the hair, urine, and nails of subjects in these areas were higher than for a control area or background levels. Other metals, including $\mathrm{Fe}, \mathrm{Mn}, \mathrm{Cr}, \mathrm{Ni}$, and $\mathrm{Pb}$, were also detected at elevated levels in all biomarkers. The levels of metals accumulated in biomarkers corresponded to the levels of those metals in the groundwater of each study area. This study, while dealing with As-enriched groundwater, demonstrates the importance of measuring the concentrations of other elements along with As.

The levels of As in all biomarkers among exposed subjects indicate medical examinations with diagnostic procedures for arsenicosis should be regularly conducted to allow timely intervention for symptomatic individuals. In addition, the consumption of As-enriched groundwater should be banned and As-free drinking water provided in the affected areas to reduce the level of As exposure. For a better understanding of metals toxicity, how the interactions among these elements may alter their toxicological effects should be further studied.

\section{Acknowledgments}

This research was financially supported by the International Environmental Research Center (IERC) at Gwangju Institute of Science and Technology (GIST), Republic of Korea and by JSPS KAKENHI Grant Number 24406009. English editing was provided by Dennis McDermott.

\section{Author Contributions}

The contributions of Penradee Chanpiwat, Seiichiro Himeno, and Suthipong Sthiannopkao to conducting research, analyzing samples, and writing the report were equal.

\section{Conflicts of Interest}

The authors declare no conflict of interest.

\section{References}

1. Briggs, D. Environmental pollution and the global burden of disease. Brit. Med. Bull. 2003, 68, 1-24. 
2. Schmoll, O.; Howard, G.; Chilton, G.; Chorus, I. Protecting Groundwater for Health: Managing the Quality of Drinking-water Resources; World Health Organization: London, UK, 2006.

3. Polya, D.A.; Gault, A.G.; Diebe, N.; Feldman, P.; Rosenboom, J.W.; Gilligan, E.; Fredericks, D.; Milton, A.H.; Sampson, M.; Rowland, H.A.L.; et al. Arsenic hazard in shallow Cambodian groundwaters. Mineral. Mag. 2005, 695, 807-823.

4. Berg, M.; Stengel, C.; Pham, T.K.; Pham, H.V.; Sampson, M.L.; Leng, M.; Semreth, S.; Fredericks, D. Magnitude of Arsenic Pollution in the Mekong and Red River Deltas-Cambodia and Vietnam. Sci. Total Environ. 2007, 372, 413-425.

5. Buschmann, J.; Berg, M.; Stengel, C.; Winkel, L.; Sampson M.L.; Trang, P.T.; Viet, P.H. Contamination of drinking water resources in the Mekong delta floodplains: Arsenic and other trace metals pose serious health risks to population. Environ. Int. 2008, 346, 756-764.

6. Sthiannopkao, S.; Kim, K.W.; Sotham, S.; Choup, S. Arsenic and manganese in tube well waters of Prey Veng and Kandal Provinces, Cambodia. Appl. Geochem. 2008, 235, 1086-1093.

7. Luu, T.T.; Sthiannopkao, S.; Kim, K.W. Arsenic and other trace elements contamination in groundwater and a health risk assessment study for the residents in the Kandal Province of Cambodia. Environ. Int. 2009, 35, 455-460.

8. Phan, K.; Sthiannopkao, S.; Kim, K.W.; Wong, M.H.; Sao, V.; Hashim, J.H.; Mohamed, Y.M.S.; Aljunid, S.M. Health risk assessment of inorganic arsenic intake of Cambodia residents through groundwater drinking pathway. Water Res. 2010, 44, 5777-5788.

9. Kim, K.W.; Chanpiwat, P.; Hanh, H.T.; Phan, K.; Sthiannopkao, S. Arsenic geochemistry of groundwater in Southeast Asia. Front. Med. 2011, 54, 420-433.

10. Adriano, D.C. Trace Elements in Terrestrial Environments: Biogeochemistry, Bioavailability, and Risks of Metals, 2nd ed.; Springer-Verlag: New York, NY, USA, 2001.

11. Issue Paper on the Human Health Effects of Metals. Available online: http://www2.epa.gov/ osa/issue-paper-human-health-effects-metals (accessed on 1 September 2015)

12. Gil, F.; Pla, A. Biomarkers as biological indicators of xenobiotics exposure. J. Appl. Toxicol. 2001, 21, 245-255.

13. Angerer, J.; Ewers, U.; Wilhelm, M. Human biomonitoring: State of the art. Int. J. Hgy. Environ. Health 2007, 210, 201-228.

14. Esteban, M.; Castano, A. Non-invasive matrices in human biomonitoring: A review. Environ. Int. 2009, 35, 438-449.

15. Clewell, H.J.; Tan, Y.M.; Campbell, J.L.; Andersen, M.E. Quantitative interpretation of human biomonitoring data. Int. J. Hgy. Environ. Health 2008, 231, 122-133.

16. Smolders, R.; Schramm, K.W.; Nickmilder, M.; Schoeters, G. Applicability of non-invasively matrices for human biomonitoring. Environ. Health 2009, 8, doi:10.1186/1476-069X-8-8.

17. Marchiset-Ferlay, M.; Savanovitch, C.; Sauvant-Rochat, M.P. What is the best biomarker to assess arsenic exposure via drinking water. Environ. Int. 2012, 35, 150-171.

18. Phan, K.; Kim, K.W.; Hashim, J.H. Environmental arsenic epidemiology in the Mekong river basin of Cambodia. Environ. Res. 2014, 135, 37-41.

19. Phan, K.; Kim, K.W.; Huoy, L.; Phan, S.; Se, S.; Capon, A.G.; Hashim, J.H. Current status of arsenic exposure and social implication in the Mekong River basin of Cambodia. Environ. Geochem. Health 2015, 8, doi:10.1007/s10653-015-9759-z. 
20. Samanta, G.; Sharma, R.; Roychowdhury, T.; Chakraborti, D. Arsenic and other elements in hair, nails, and skin-scales of arsenic victims in West Bengal, India. Sci. Total Environ. 2004, 326, 33-47.

21. Gault, A.G.; Rowland, H.A.L.; Charnock, J.M.; Wogelius, R.A.; Gomez-Morilla, I.; Vong, S.; Leng, M.; Samreth, S.; Sampson, M.L., Polya, D.A. Arsenic in hair and nails of individuals exposed to arsenic-rich groundwaters in Kandal province, Cambodia. Sci. Total Environ. 2008, 393, $168-176$.

22. Chen, K.L.; Amarasiriwardena, C.J.; Christiani, D.C. Determination of total arsenic concentrations in nails by inductively coupled plasma mass spectrometry. Biol. Trace Elem. Res. 1999, 67, 109-125.

23. Hossain, E.; Islam, K.; Yeasmin, F.; Karim, M.R.; Rahman, M.; Agarwal, S.; Hossain, S.; Aziz, A.; Mamun, A.A.; Sheikh, A.; et al. Elevated levels of plasma Big endothelin-1 and its relation to hypertension and skin lesions in individuals exposed to arsenic. Toxicol. Appl. Pharm. 2012, 259, 187-194.

24. Guidelines for Drinking-Water Quality. Available online: http://www.who.int/ water_sanitation_health/publications/2011/dwq guidelines/en/ (accessed on 1 September 2015).

25. Phan, K.; Phan, S.; Heng, S.; Huoy, L.; Kim, K.W. Assessing arsenic intake from groundwater and rice by residents in Prey Veng province, Cambodia. Environ. Pollut. 2014, 185, 84-89.

26. Phan, K.; Phan, S.; Huoy, L.; Suy B.; Wong, M.H.; Hashim, J.H.; Yasin, M.S.M.; Aljunid, S.M.; Sthiannopkao, S.; Kim, K.W. Assessing mixed trace elements in groundwater and their health risk of residents living in the Mekong River basin of Cambodia. Environ. Pollut. 2013, 182, 111-119.

27. ATSDR. ToxGuide ${ }^{\mathrm{TM}}$ for Arsenic. Available online http://www.atsdr.cdc.gov/toxguides/ toxguide-2.pdf (accessed on 1 September 2015)

28. Sthiannopkao, S.; Kim, K.W.; Cho, K.H.; Wantala, K.; Sotham, S.; Sokuntheara, C.; Kim, J.H. Arsenic levels in human hair, Kandal province, Cambodia: The influences of groundwater arsenic, consumption period, age and gender. Appl. Geochem. 2010, 25, 81-90.

29. Sampson, M.L.; Bostick, B.; Chiew, H.; Hagan, J.M.; Shantz, A. Arsenicosis in Cambodia: Case studies and policy response. Appl. Geochem. 2008, 23, 2977-2986.

30. Hughes, M.F. Biomarkers of exposure: A case study with inorganic arsenic. Environ. Health Perspect. 2006, 114, 1790-1796.

31. Coelho, P.; Costa, S.; Silva, S.; Walter, A.; Ranville, J.; Sousa, A.C.A.; Costa, C.; Coelho, M.; Garcia-Leston, J.; Pastorinho, M.R.; et al. Metal(Loid) levels in biological matrices from human populations exposed to mining contamination-Panasqueira Mine (Portugal). J. Toxicol. Environ. Health A 2012, 75, 893-908.

32. Looney, S.W. Statistical methods for assessing biomarkers. Methods Mol. Biol. 2002, 184, 81-109.

33. Phan, K.; Sthiannopkao, S.; Kim, K.W. Surveillance on chronic arsenic exposure in the Mekong River basin of Cambodia using different biomarkers. Int. J. Hyg. Environ. Health 2011, 215, 51-58.

34. Wang, H.S.; Sthiannopkao, S.; Chen, Z.J.; Man, Y.B.; Du, J.; Xing, G.H.; Kim, K.W.; Mohammad, Y.M.S.; Hashim, J.H.; Wong, M.H. Arsenic concentrations in rice fish, and meat and vegetables in Cambodia: A study risk assessment. Environ. Geochem. Health 2013, 35, 745-755.

(C) 2015 by the authors; licensee MDPI, Basel, Switzerland. This article is an open access article distributed under the terms and conditions of the Creative Commons Attribution license (http://creativecommons.org/licenses/by/4.0/). 